\title{
Modifying the physical properties of butter using high-intensity ultrasound
}

\section{Jiwon Lee and Silvana Martini*}

Department of Nutrition, Dietetics, and Food Sciences, Utah State University, Logan 83422-8700

\section{ABSTRACT}

The physical qualities of butter are affected by the physical properties of the cream used to make it. The objective of this study was to evaluate the effect of high-intensity ultrasound (HIU) on the physical properties of cream and butter. High-intensity ultrasound (frequency: $20 \mathrm{kHz}$, amplitude: $108 \mu \mathrm{m}$ ), often called sonication, was applied for $0,10,30,60$, and $90 \mathrm{~s}$ using a 1.27 -cm-diameter tip to heavy cream ( $40 \%$ fat; $300 \mathrm{~g})$ that was aged at $7.5^{\circ} \mathrm{C}$ with low agitation $(40$ rpm) for $90 \mathrm{~min}$. Sonicated cream was churned at $7.5^{\circ} \mathrm{C}$ until butter grains were formed. The solid fat content (SFC), melting behavior, and average fat droplet size of cream were measured after HIU treatment. Butter was characterized by SFC and melting behavior immediately after production and was tested for SFC, melting behavior, and hardness after storage for $24 \mathrm{~h}$ at $5^{\circ} \mathrm{C}$. High-intensity ultrasound did not affect the average fat droplet size of cream. Sonicating cream for 30, 60, and 90 s slightly decreased SFC due to the temperature increase $\left(2-6^{\circ} \mathrm{C}\right)$ that occurred during HIU application. Two melting peaks were observed at approximately 17 and $33^{\circ} \mathrm{C}$ in all the cream samples. A significantly lower peak temperature was observed in cream sonicated for $10 \mathrm{~s}$ compared with creams sonicated for 30 and $60 \mathrm{~s}$. A relatively shorter churning time of sonicated cream compared with nonsonicated cream was observed, possibly because HIU weakens the fat globule membrane. Two melting peaks were observed in all butter samples at approximately 16 and $33^{\circ} \mathrm{C}$. Treatment with HIU for 10 to $60 \mathrm{~s}$ significantly increased the hardness of butter. When HIU was applied to cream for $10 \mathrm{~s}$, the hardest butter was obtained, with the lowest onset temperatures and highest enthalpy values for both melting peaks. Treatment with HIU for $10 \mathrm{~s}$ promoted crystallization of low-melting-point triacylglycerols (TAG) during churning, which resulted in a harder material. Significantly lower enthalpy values for the high-melting-

Received May 16, 2018.

Accepted November 12, 2018.

*Corresponding author: silvana.martini@usu.edu fraction TAG were observed in butters treated with HIU for 60 and $90 \mathrm{~s}$ compared with non-HIU-treated butter, which suggests that a longer duration of HIU promotes melting of high-melting-point TAG. The hardness of butter was correlated with the enthalpy values of the low-melting fraction and with total enthalpy values of fresh butter. However, further crystallization occurred in the butter during $24 \mathrm{~h}$ of storage at $5^{\circ} \mathrm{C}$, and all differences in enthalpy values disappeared. In conclusion, exposure of cream to HIU can be used to modify the physical properties of butter, and the effects of HIU depend on the length of HIU treatment.

Key words: high-intensity ultrasound, crystallization, cream, butter, hardness

\section{INTRODUCTION}

Butter consumption in the United States is continuously increasing and reached a value of $2.6 \mathrm{~kg} /$ person in 2016 (USDA, 2017). Butter is used as a condiment and a baking ingredient, providing flavor and body to foods. For many years, the physical properties of butter have been modified to broaden its functionality. For example, milk fatty acid composition has been altered to modify butter texture by feeding cows a high content of unsaturated fat (MacGibbon et al., 2002; Bobe et al., 2003). Fatty acid composition has also been changed by using fractionated milk fats. Addition of the olein fraction into cream before aging modifies the physical properties of butter, such as texture and color (Queiros et al., 2016). Combining different milk fat fractions has been also studied to modify the texture and melting behavior of recombined butter (Kaylegian and Lindsay, 1992; Frede and Buchheim, 1994).

In butter manufacturing, cream aging is the most time-consuming processing step. Fat crystallization in cream during aging is an important process that affects churning time, texture, and mouthfeel of butter. Crystallization in cream is controlled by cooling rate, storage temperature, and agitation rate during aging and churning after pasteurization (Rønholt et al., 2012, 2014). During the aging process, liquid oil in the milk fat globules in cream starts crystallizing. Partially crystallized fat globules form a continuous network by 
partial coalescence during churning. The amount and size of crystals in cream can be adjusted by controlling the temperature and time of the aging process and by temperature fluctuations before churning. Rapid cooling can cause a large quantity of small crystals in the cream (Wiking et al., 2009), which can produce firm butter, whereas slow cooling of the cream for a long time can produce soft butter (Wiking et al., 2009).

High-intensity ultrasound (HIU) has been used to control crystallization in food systems. It has been studied intensively to induce crystallization of ice and bulk lipid (Higaki et al., 2001; Chow et al., 2005; Martini et al., 2008; Ye et al., 2011). Crystallization occurs through nucleation and growth, and nucleation consists of primary and secondary nucleation. Primary nucleation can occur homogeneously or heterogeneously. Homogeneous nucleation occurs when nuclei are formed without pre-existing crystals, whereas heterogeneous nucleation occurs when nuclei are formed by foreign substances, such as air bubbles, dirt, or a scratch on the wall. Secondary nucleation is induced by preexisting crystals. Theoretically, HIU can promote crystallization by inducing both homogeneous and secondary nucleation (Chow et al., 2003, 2005) through the generation of cavitation.

When HIU is introduced in a medium, the acoustic waves generate voids or bubbles that go through a series of compression and rarefaction cycles. When a bubble is exposed to the acoustic wave, it grows to a maximum size, often with collapse of the bubble. Upon the bubble's collapse, high localized pressures and temperatures can generate an increase in supercooling (Hickling, 1994). This increased supercooling initiates primary nucleation (Kiani et al., 2011). In addition, the shear forces generated by bubbles collapsing can break existing crystals, generating a nucleus for secondary crystallization (Chow et al., 2003). It is thought that any stable bubbles generated by HIU can act as nuclei and induce crystallization. The effect of HIU on crystallization depends on acoustic parameters such as power level, intensity, probe size, probe immersion depth, sample size, and duration (Chemat et al., 2004; Nishida, 2004; Luque de Castro and Priego-Capote, 2007; Martini et al., 2008; Suzuki et al., 2010). In addition, crystallization temperature, degree of crystallization, and type of medium modifying the effect of HIU on crystallization behavior of the material (Martini et al., 2008; Ye et al., 2011).

Beyond the use of sonication to induce lipid crystallization, HIU has been used in oil-in-water $(\mathbf{o} / \mathbf{w})$ emulsions to make smaller droplets. Gaikwad and Pandit (2008) reported that a longer duration of sonication could increase the volume of the dispersed phase and decrease the dispersed phase droplet size. Small droplets are more prone to crystallize faster due to the increased supercooling inside the milk fat globules in cream (Lopez et al., 2002). A reduction in droplet size in sonicated o/w emulsions has been observed in other studies (Cheng et al., 2007; Yang et al., 2008; Maghsoudlou et al., 2016). Maghsoudlou et al. (2016) noted that shear forces generated by HIU reduced the particle sizes of almond milk. Shanmugam and Ashokkumar (2014) reported that a longer HIU application at high power significantly reduced the size of fat globules due to slight denaturation of whey proteins that act as surfactants in milk. These physical changes are expected to modify crystallization behavior in milk. Although HIU has been used to form o/w emulsions, it is unclear whether it affects crystallization in the emulsion's droplets. In addition, the effect of HIU on phase inversion from an $\mathrm{o} / \mathrm{w}$ emulsion such as cream to a water-in-oil emulsion such as butter has not yet been studied. The hypothesis of this study is that HIU can be used to modify the physical properties of butter such as texture and melting behavior by changing the type of crystallized triacylglycerols (TAG) and droplet sizes in aged cream, which in turn affect crystallization behavior during churning. Therefore, the objective of this study was to explore the effect of HIU of cream on the physical properties of cream and butter.

\section{MATERIALS AND METHODS}

\section{Butter Making}

Pasteurized heavy whipping cream (40\% fat; Organic Valley, La Farge, WI) was purchased at a local grocery store. Cream $(300 \mathrm{~g})$ was heated to $55^{\circ} \mathrm{C}$ in an oven to erase crystal memory and then transferred into a jar in a water bath at $7.5^{\circ} \mathrm{C}$, which represents a normal aging temperature (Chandan et al., 2015). Cream was aged for 90 min with agitation by using an overhead stirrer (RW basic 16, IKA, Wilmington, NC) at $40 \mathrm{rpm}$. After 90 min of aging, HIU (20 kHz) was applied to cream for $0,10,30,60$, or 90 s at setting $9(85 \mathrm{~W})$ using a Misonix S-3000 sonicator and 1.27-cm-diameter probe (Misonix Inc., Farmingdale, NY) with a vibration amplitude of $108 \mu \mathrm{m}$. While HIU was being applied, the temperature of the sample was measured to check for temperature increase in the cream. After HIU treatment, the cream was transferred to a KitchenAid 2-quart ice cream maker (KICA0WH) stand mixer attachment (KitchenAid, Benton Harbor, MI). The outer surface of the ice cream maker bowl was punctured at 2 different spots to remove the chemical that was inside the bowl and to connect to a water bath to allow water circulation for temperature control. The cream was churned using a KitchenAid mixer (model K5-A, KitchenAid, Troy, OH; 
speed setting 9) at $7.5^{\circ} \mathrm{C}$ until buttermilk was separated from butter grains. After churning, butter grains were collected in a cheesecloth and were gently squeezed using a butter press (Maple \& Cherry Butter Press, The Cheesemaker, Mequon, WI) to remove the buttermilk. Drained buttermilk and pressed butter were weighed, and the ratio of produced butter and buttermilk was calculated from 3 experimental replicates. Fresh butter was tested for solid fat content (SFC), melting behavior, and water content. The remaining butter was stored at $5^{\circ} \mathrm{C}$ for $24 \mathrm{~h}$ and then tested for SFC, melting behavior, and texture. Butter was prepared under each condition in triplicate (experimental replicate).

\section{Solid Fat Content}

The amount of crystalline fat present in the cream was measured using a pulsed-nuclear magnetic resonance (p-NMR) analyzer (Minispec mq-20, Bruker Inc., Billerica, MA) following the AOCS Cd 16b-93 method (AOCS, 2009). While cream was being aged, SFC was measured every $5 \mathrm{~min}$ for $60 \mathrm{~min}$ and then every 10 min until 90 min. Solid fat content was also measured immediately after HIU treatment and butter production and after stored at $5^{\circ} \mathrm{C}$ for $24 \mathrm{~h}$. It was measured (once for each experimental replicate) by transferring approximately $2 \mathrm{~mL}$ of cream or butter $(1 \mathrm{~cm}$ height $)$ to a NMR tube $(10 \mathrm{~mm}$ in diameter and $180 \mathrm{~mm}$ in height).

\section{Fat Droplet Size}

Droplet size was quantified for all the cream samples using a Beckman Coulter particle characterization equipment (LS230 Version 3.19; Beckman Coulter Inc., Indianapolis, IN). After 90 min of aging, sonicated and nonsonicated cream samples $(15 \mathrm{~mL})$ were collected and used for the measurement. Droplet size was expressed as Sauter mean diameter $\left(\mathbf{D}_{3,2}\right)$ value and calculated as follows:

$$
\mathrm{D}_{3,2}=\frac{\sum n_{i} d_{i}^{3}}{\sum n_{i} d_{i}^{2}},
$$

where $d_{i}$ is the diameter of the particles in each size class, and $n_{i}$ is the number of particles in each size per class unit volume of emulsion (McClements, 2004). Each experimental replicate was measured in triplicate.

\section{Melting Behavior}

A differential scanning calorimeter (Q20, TA Instruments, Castle, DE) was used to evaluate melting behav- ior of cream aged for $90 \mathrm{~min}$, fresh butter, and butter stored for $24 \mathrm{~h}$ at $5^{\circ} \mathrm{C}$. Between 7 and $11 \mathrm{mg}$ of each sample was placed into aluminum hermetic pans and sealed. An empty cell was used as a reference. Cream was heated from aging temperature to $60^{\circ} \mathrm{C}$ at a ramp rate of $5^{\circ} \mathrm{C} / \mathrm{min}$. Melting behavior was quantified with the onset melting temperature $\left(\mathbf{T}_{\text {on }},{ }^{\circ} \mathrm{C}\right)$, peak melting temperature $\left(\mathbf{T}_{\mathrm{p}},{ }^{\circ} \mathrm{C}\right)$, and change in enthalpy $(\boldsymbol{\Delta H}$, $\mathrm{J} / \mathrm{g}$ of fat) associated with the melting process. These parameters were measured using the TA Universal Analysis software (TA Instruments). Melting behavior was measured once for each experimental replicate.

\section{Water Content}

Water content was measured as described in Rønholt et al. (2012). Fresh butter (5 g) was placed in a porcelain cup and stored in an oven at $100^{\circ} \mathrm{C}$ for $2 \mathrm{~h}$. Then, the cup was placed in a desiccator at room temperature for $30 \mathrm{~min}$. When the sample reached room temperature, the cup was weighed and water loss from the sample was calculated as percentage of the initial weight. Water content was measured in triplicate from 3 experimental replicates.

\section{Texture}

The texture (hardness) of the samples was measured as described by Cisneros Estevez et al. (2013) with modifications. A penetrometry test was performed on butter that was stored at $5^{\circ} \mathrm{C}$ for $24 \mathrm{~h}$ using a Texture Profile Analyzer (TA-XT plus Texture Analyzer, Texture Technologies Corp./Stable Micro Systems Ltd., Hamilton, MA) with spreadability rig TA-425 TTC (Texture Technologies Corp.). The rig was composed of a matched cup and $90^{\circ}$ cone probe. For height calibration, the empty cup was mounted on the bottom, and the probe was calibrated to be positioned at $25 \mathrm{~mm}$ (the starting position) from the cup, having a touch force of $10 \mathrm{~g}$. For the firmness test, the probe was set up to travel $23 \mathrm{~mm}$ (leaving a 2-mm gap between the bottom of the cup and the cone probe) from the starting position $(25 \mathrm{~mm})$ at a rate of $3 \mathrm{~mm} / \mathrm{s}$ to reach the maximum penetration depth and return to the starting position. After the calibration and program setup, butter sample was placed into 5 cups. Excessive butter on the cup was scraped to flatten the top surface. The cups were kept at room temperature $\left(23^{\circ} \mathrm{C}\right)$ for $60 \mathrm{~min}$ before performing the test. The force $(\mathrm{g})$ required for the probe to travel $23 \mathrm{~mm}$ as a function of time (s) was plotted. The peak force required to reach the maximum penetration depth was used for firmness of the butter sample, which was then converted to newtons (N). Five measurements were performed for each sample. 


\section{Statistical Analysis}

All data were analyzed using Prism 7.0 (GraphPad Prism Inc., La Jolla, CA). Tukey's multiple comparisons were used for one-way ANOVA for $\mathrm{D}_{3,2}$ values of fat droplet size of cream and firmness, melting behavior, water content, and SFC of butter. The correlation between fat droplet size of cream, medium melting peak enthalpy, high melting peak enthalpy, total enthalpy, and SFC of cream, fresh butter, and 1-d-old butter were analyzed. Statistical differences were evaluated at an $\alpha=0.05$ level of significance.

\section{RESULTS AND DISCUSSION}

\section{Effect of HIU on the Physical Properties of Cream}

Solid Fat Content. The SFC increased rapidly at $7.5^{\circ} \mathrm{C}$ after 6 min of aging and reached about $14.5 \pm$ $0.3 \%$ after 90 min (Figure $1 \mathrm{~A}$ ). The increase in SFC slowed after 22 min of aging but did not reach a plateau and it increased slightly after 60 min of aging. An instant temperature increase of $2 \pm 0.1,3 \pm 0.4$, $5 \pm 0.1$, and $6 \pm 0.1^{\circ} \mathrm{C}$ was observed in creams during sonication for 10, 30, 60, and 90 s, respectively. Because of the increase in temperature, SFC in cream after HIU treatment decreased slightly, as shown in Figure 1B, and this difference became significant in the cream samples that were sonicated for $90 \mathrm{~s}$ compared with nonsonicated cream $(P<0.05)$.

Droplet Size. Average droplet size of cream samples after $90 \mathrm{~min}$ of aging was measured as Sauter mean diameter $\left(\mathrm{D}_{3,2}\right.$; Figure $\left.2 \mathrm{~A}\right)$. The average droplet size was $1.9 \pm 0.1 \mu \mathrm{m}$ and was not affected by sonication $(P>0.05)$, indicating that HIU did not significantly affect the $D_{3,2}$ value of the cream regardless of duration. It is possible that this lack of effect is due to the lower power level, which was $85 \mathrm{~W}$, and the short exposure time to HIU in the current study. Abismail et al. (1999) studied the effect of different HIU power levels and exposure times to HIU on droplet sizes in $\mathrm{o} / \mathrm{w}$ emulsions. Their results showed that the use of HIU $(20 \mathrm{kHz}, 90-130 \mathrm{~W})$ for $30 \mathrm{~s}$ decreased the $\mathrm{D}_{3,2}$ value of droplets in $\mathrm{o} / \mathrm{w}$ emulsions with a surfactant and that higher power resulted in a smaller $\mathrm{D}_{3,2}$ value. The greatest reduction in droplet size occurred in the first $15 \mathrm{~s}$ of sonication, and no reduction was observed after $30 \mathrm{~s}$ at a power level of $130 \mathrm{~W}$ as shown in the study of Abismail et al. (1999). Those authors showed that a high power level is required to reduce droplet size when HIU is applied for shorter periods. Cucheval and Chow (2008) observed a reduction in oil droplet size (volume-weighted diameter, $\mathrm{D}_{4,3}$ ) in a soybean oil-
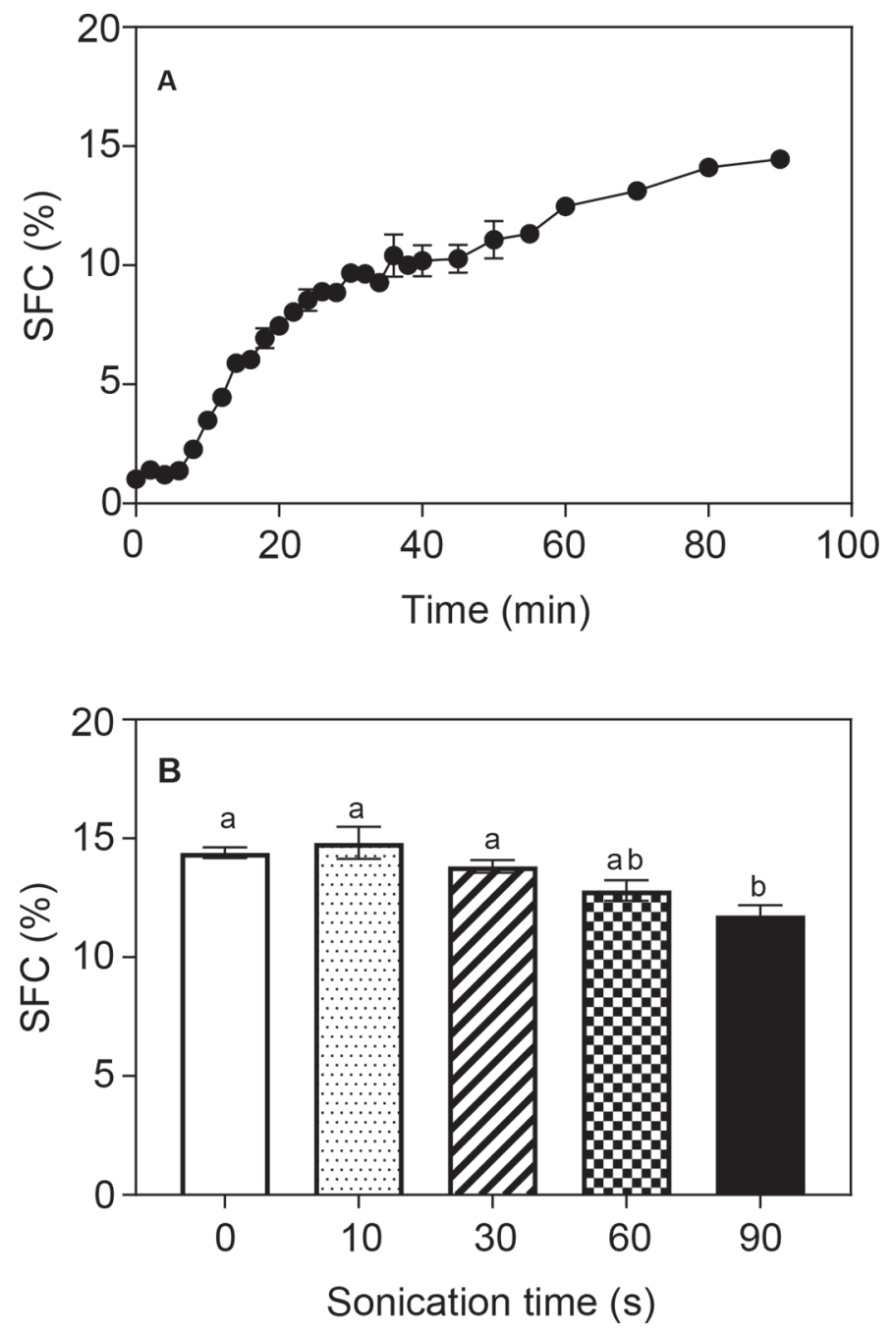

Figure 1. Solid fat content (SFC) in cream (A) aged at $7.5^{\circ} \mathrm{C}$ for $90 \mathrm{~min}$, and (B) after high-intensity ultrasound treatment for 0,10 , 30,60 , and $90 \mathrm{~s}$. The error bars represent $\operatorname{SEM}(\mathrm{A}: \mathrm{n}=2, \mathrm{~B}: \mathrm{n}=3)$. Values sharing letters $(\mathrm{a}, \mathrm{b})$ are not significantly different $(P>0.05)$.

in-water emulsion by applying HIU (20 kHz, 18-47 W) for 1 to $15 \mathrm{~min}$ for emulsification. Those authors found a tendency for a more rapid decrease in larger droplets with higher power and a decrease in standard deviation with a longer duration. Even though a significant decrease in average size was not observed in our study, a slight decrease in the volume of large droplets was observed as a function of sonication time (Figure 2B). Application of $\mathrm{HIU}$ resulted in more small droplets and fewer large droplets: the volume of droplets with diameters between 0 and $2 \mu \mathrm{m}$ slightly increased and that of droplets with diameters between 3 and $5 \mu \mathrm{m}$ decreased (Figure 2B). This effect was more obvious in the cream sonicated for $90 \mathrm{~s}$, as shown in Figure 2B, 
which shows that the volume of large droplets (between 3 and $5 \mu \mathrm{m}$ in diameter) was noticeably lower than that of the other conditions. The average droplet of the cream sonicated for $90 \mathrm{~s}$ was significantly smaller than that of nonsonicated sample $(P<0.05)$ when only the $\mathrm{D}_{3,2}$ values under these 2 conditions were compared (data are not shown). This suggests that longer sonication times $(>90 \mathrm{~s})$ can reduce average droplet size at the power setting used in the current study.

Melting Behavior. All cream samples showed 2 melting peaks - the medium-melting-fraction (MMF) and the high-melting-fraction (HMF) peaks (Figure $3 \mathrm{~A})$. The lowest $\mathrm{T}_{\text {on }}$ for the MMF peak was $13.2^{\circ} \mathrm{C}$ and
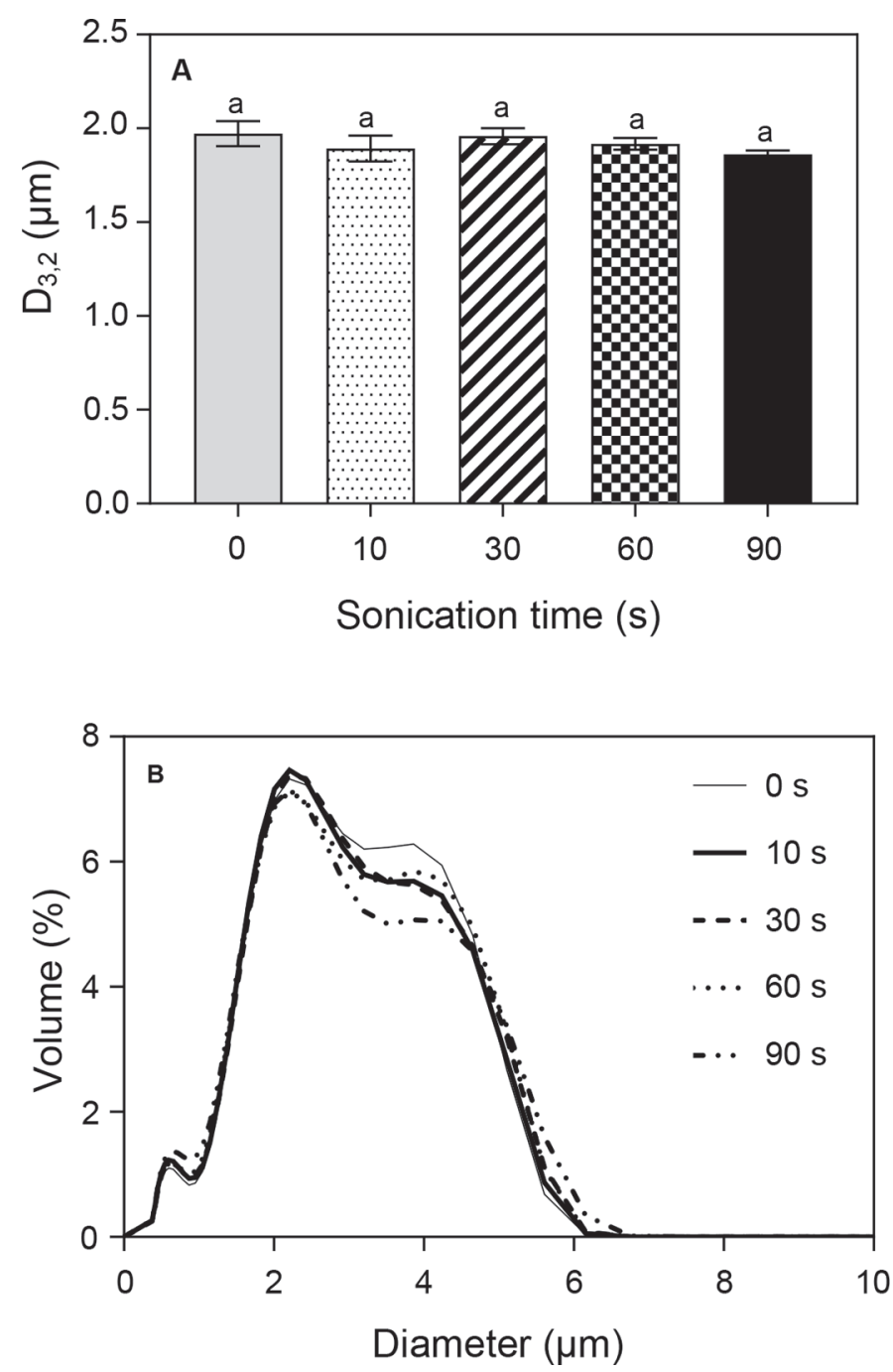

Figure 2. Sauter mean diameter $\left(\mathrm{D}_{3,2}\right)$ values $(\mathrm{A})$, and droplet size distribution (B) of fat droplets in cream that was aged at $7.5^{\circ} \mathrm{C}$ for 90 min and sonicated for $0,10,30,60$, and $90 \mathrm{~s}$. The error bars represent SEM $(\mathrm{n}=3)$. Values sharing letters (a) are not significantly different $(P>0.05)$ the highest was $14.3^{\circ} \mathrm{C}$ (Table 1 ). Sonication did not affect $(P>0.05)$ the $\mathrm{T}_{\text {on }}$ of the MMF or HMF peaks. Peak temperatures for MMF ranged from 16.4 to $17.2^{\circ} \mathrm{C}$, and those for HMF ranged from 32.2 to $33.2^{\circ} \mathrm{C}$ (Table 1 ). Cream sonicated for $10 \mathrm{~s}$ had the lowest $\mathrm{T}_{\mathrm{p}}$ for both MMF and HMF, which were significantly lower $(P<$ $0.05)$ than the $T_{p}$ obtained for cream sonicated for 30 and $60 \mathrm{~s}(P<0.05)$. This suggests that sonication for long periods either promotes the crystallization of higher-melting-point TAG or melts the low-melting-point TAG, resulting in a higher $T_{p}$. Considering the increase in temperature observed during sonication, it is likely that sonication for $>30 \mathrm{~s}$ melts the low-melting-point TAG of the MMF and HMF. The enthalpy values of the MMF were $1.3 \mathrm{~J} / \mathrm{g}$ of fat and those of HMF were $10.2 \mathrm{~J} / \mathrm{g}$ of fat. Although no significant differences were observed among total melting enthalpy values, some tendencies were observed. The lowest total enthalpy, $11.7 \mathrm{~J} / \mathrm{g}$ of fat, was observed in cream sonicated for 60 $\mathrm{s}$ and the highest in cream sonicated for $10 \mathrm{~s}$ (17.6 \pm $1.3 \mathrm{~J} / \mathrm{g}$ of fat; mean $\pm \mathrm{SEM})$. These data follow a similar tendency to the SFC reported in Figure 1B. Even though significantly lower SFC values were observed in cream sonicated for $90 \mathrm{~s}$, this was not reflected in the melting enthalpy values. Overall, few differences were observed in the melting profiles of cream as a function of sonication, suggesting that sonication did not greatly affect the type and amount of crystals formed in the cream during aging.

\section{Effect of HIU on Physical Properties of Butter}

Melting Behavior. Two melting peaks (MMF and HMF) were observed in both fresh and 1-d-old butter samples (Figures $3 \mathrm{~B}$ and $\mathrm{C}$ ). In fresh butter, the $\mathrm{T}_{\text {on }}$ of the MMF ranged from 13 to $15^{\circ} \mathrm{C}$ and the $\mathrm{T}_{\mathrm{p}}$ was approximately $16.2^{\circ} \mathrm{C}$ (Table 2). Sonication for $10 \mathrm{~s}$ significantly lowered $\mathrm{T}_{\mathrm{on}}(P<0.005)$ and $\mathrm{T}_{\mathrm{p}}(P<0.01)$ of the MMF of fresh butter. As sonication time increased to 30,60 , and $90 \mathrm{~s}$, the $\mathrm{T}_{\text {on }}$ values gradually increased but did not reach the value obtained for butter made with nonsonicated cream. Similarly, $\mathrm{T}_{\mathrm{p}}$ values increased with sonication time to values close to those obtained for butter made with nonsonicated cream. Lower $\mathrm{T}_{\text {on }}$ values suggest that sonication promoted crystallization of lower melting fats in butter. This effect was more pronounced when the cream was sonicated for $10 \mathrm{~s}$ because, in this case, the $T_{p}$ value was significantly lower than that obtained in butter made with nonsonicated cream. In addition, sonication for $<30 \mathrm{~s}$ significantly increased the melting enthalpy values of $\operatorname{MMF}(P<$ 0.05 ), suggesting an overall induction in the crystallization of MMF TAG. The weaker effect of sonication 

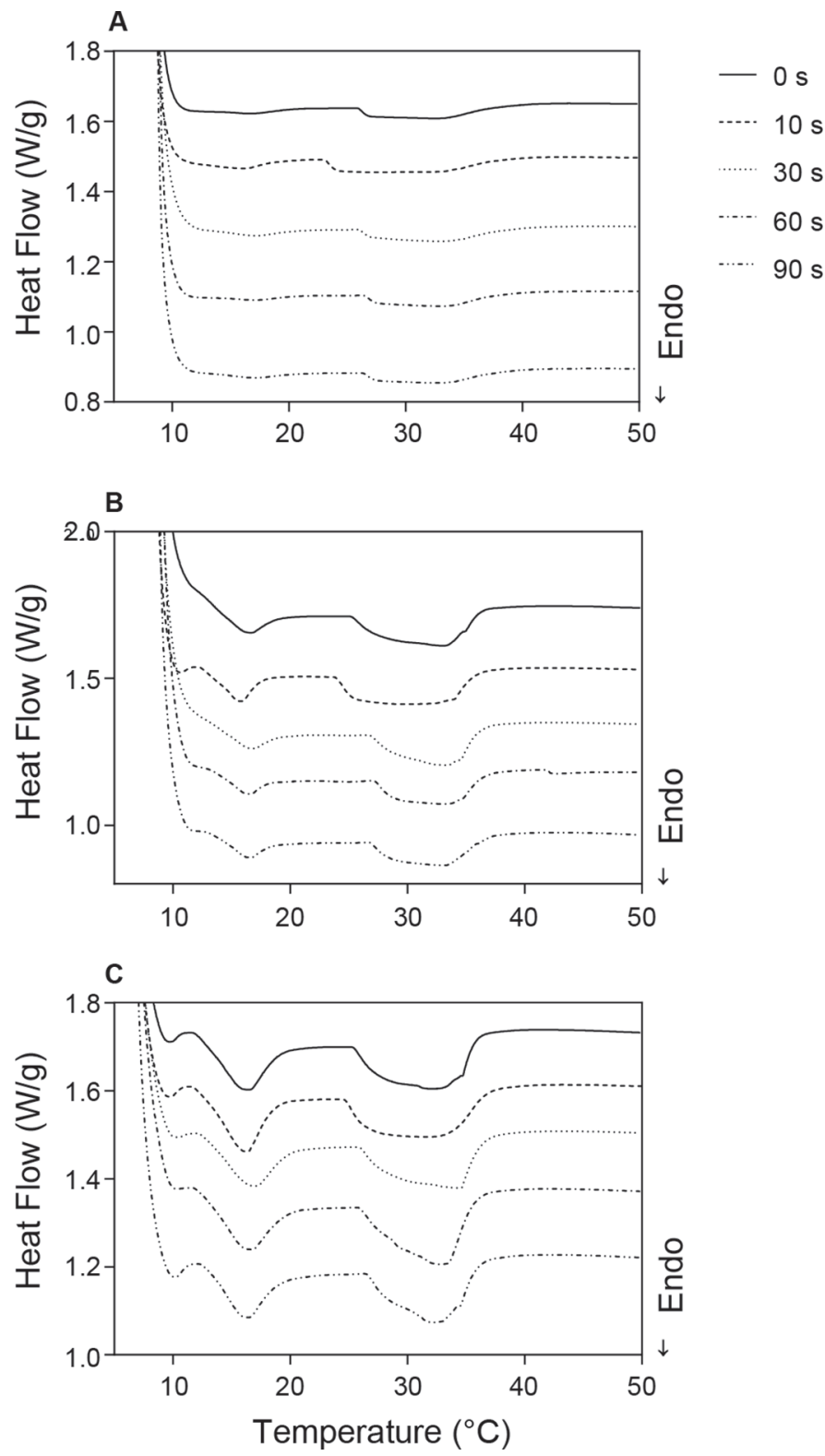

Figure 3. Melting profiles of (A) cream, (B) fresh butter, and (C) 1-d-old butter (stored for $24 \mathrm{~h}$ at $5^{\circ} \mathrm{C}$ ). Cream was aged at $7.5^{\circ} \mathrm{C}$ for $90 \mathrm{~min}$ and sonicated for $0,10,30,60$, and $90 \mathrm{~s}$, and churned at $7.5^{\circ} \mathrm{C}$. Endo $=$ endothermic process.

for longer duration can be attributed to the increase in temperature during sonication, as previously discussed. Even though few changes were observed in the melting profiles of cream as a function of sonication, it is likely that some degree of change in crystal formation is initiated at that stage that is not detected by differential scanning calorimetry. Upon the further crystallization that occurs during churning, these effects become more significant and are evident in the differential scanning calorimetry profiles. It is possible that MMF nuclei are formed during sonication of the cream for $10 \mathrm{~s}$ and that these nuclei grow during churning and butter formation. No significant differences were found in $\mathrm{T}_{\mathrm{on}}$ and $T_{p}$ values of the HMF sonicated for 30,60 , and $90 \mathrm{~s}$ compared with nonsonicated. Sonication for $10 \mathrm{~s}$ resulted in lower $\mathrm{T}_{\mathrm{on}}$ and $\mathrm{T}_{\mathrm{p}}$ compared with all other samples $(P<0.05)$. Exposure to HIU for more than 30 s significantly reduced enthalpy values of $\operatorname{HMF}(P<$ $0.05)$. This suggests that even though HIU used for $10 \mathrm{~s}$ does not induce the crystallization of HMF, sonication for long periods (>30 s) inhibits or delays crystallization of low-melting-point TAG. These results are similar to those previously discussed for cream. However, as previously noted, HIU can promote the crystallization of MMF when cream is exposed to HIU for $10 \mathrm{~s}$.

When the butter was stored for $24 \mathrm{~h}$ at $5^{\circ} \mathrm{C}$ (Figure $3 \mathrm{C}$ ), further crystallization occurred, as evidenced by the increase in enthalpy values (Table 2). The total enthalpy of fresh butter samples increased after $24 \mathrm{~h}$ of storage at $5^{\circ} \mathrm{C}$ except in butter that was made with cream sonicated for $10 \mathrm{~s}$. The increase in enthalpy values was seen mainly in the MMF, suggesting that storage at $5^{\circ} \mathrm{C}$ promoted crystallization of low-melting TAG. This is also supported by the decrease in $T_{\text {on }}$ values of the MMF peaks. After storage at $5^{\circ} \mathrm{C}$, sonication did not affect any of the melting parameters of the butter $(P>0.05)$.

Hardness. Hardness was measured in butter stored at $5^{\circ} \mathrm{C}$ for $24 \mathrm{~h}$ (Figure 4 ). The effect of sonication on hardness was related to the length of exposure to HIU. Significantly firmer butter $(P<0.05)$ was produced with cream sonicated for 10,30 , and $60 \mathrm{~s}$. The hardest butter was produced with cream that was sonicated for $10 \mathrm{~s}(P<0.05)$. Sonicating cream for $90 \mathrm{~s}$ significantly decreased the hardness compared with sonicating for 10 $\mathrm{s}(P<0.0001)$ and resulted in significantly lower SFC $(P<0.05$; Table 3$)$. Sonicating for $10 \mathrm{~s}$ was the most effective condition to increase the hardness of butter.

Sonication did not affect the ratio of buttermilk and butter produced after churning (data not shown). No significant difference was found in the water content of butter made with cream sonicated for various times $(P$ $>0.05$; data not shown); therefore, water content does not explain the differences in hardness. The degree of initial crystallization in fresh butter seems to be an important factor to determine the firmness of butter. It is proposed that sonication induces crystallization of low-melting-point TAG in the MMF, as shown in the melting profiles of the fresh butters, but these differences disappear upon cooling at $5^{\circ} \mathrm{C}$ because of the high supercooling in the sample. It is possible that the presence of these low-melting-point TAG plays an 
Table 1. Melting behavior of cream that was aged at $7.5^{\circ} \mathrm{C}$ for $90 \mathrm{~min}$ and sonicated for $0,10,30,60$, or $90 \mathrm{~s}$

\begin{tabular}{|c|c|c|c|c|c|}
\hline \multirow[b]{2}{*}{ Parameter $^{1}$} & \multicolumn{5}{|c|}{ Sonication time } \\
\hline & $0 \mathrm{~s}$ & $10 \mathrm{~s}$ & $30 \mathrm{~s}$ & $60 \mathrm{~s}$ & $90 \mathrm{~s}$ \\
\hline $\mathrm{T}_{\text {on- } 1}\left({ }^{\circ} \mathrm{C}\right)$ & $13.8 \pm 0.2^{\mathrm{a}}$ & $13.2 \pm 0.2^{\mathrm{a}}$ & $14.0 \pm 0.3^{\mathrm{a}}$ & $14.3 \pm 0.2^{\mathrm{a}}$ & $14.1 \pm 0.3^{\mathrm{a}}$ \\
\hline $\mathrm{T}_{\mathrm{p}-1}\left({ }^{\circ} \mathrm{C}\right)$ & $16.7 \pm 0.2^{\mathrm{ab}}$ & $16.4 \pm 0.2^{\mathrm{b}}$ & $17.2 \pm 0.1^{\mathrm{a}}$ & $17.3 \pm 0.1^{\mathrm{a}}$ & $17.1 \pm 0.1^{\mathrm{ab}}$ \\
\hline$\Delta \mathrm{H}_{1}(\mathrm{~J} / \mathrm{g}$ of fat $)$ & $1.4 \pm 0.1^{\mathrm{a}}$ & $1.4 \pm 0.1^{\mathrm{a}}$ & $1.3 \pm 0.3^{\mathrm{a}}$ & $1.0 \pm 0.2^{\mathrm{a}}$ & $1.4 \pm 0.3^{\mathrm{a}}$ \\
\hline $\mathrm{T}_{\text {on- } 2}\left({ }^{\circ} \mathrm{C}\right)$ & $24.6 \pm 0.8^{\mathrm{a}}$ & $24.9 \pm 1.4^{\mathrm{a}}$ & $26.4 \pm 0.6^{\mathrm{a}}$ & $26.5 \pm 0.5^{\mathrm{a}}$ & $26.1 \pm 0.5^{\mathrm{a}}$ \\
\hline $\mathrm{T}_{\mathrm{p}-2}\left({ }^{\circ} \mathrm{C}\right)$ & $32.6 \pm 0.3^{\mathrm{ab}}$ & $32.2 \pm 0.1^{\mathrm{b}}$ & $33.2 \pm 0.1^{\mathrm{a}}$ & $33.2 \pm 0.1^{\mathrm{a}}$ & $32.7 \pm 0.2^{\mathrm{ab}}$ \\
\hline$\Delta \mathrm{H}_{2}(\mathrm{~J} / \mathrm{g}$ of fat $)$ & $11.1 \pm 0.3^{\mathrm{a}}$ & $12.6 \pm 1.0^{\mathrm{a}}$ & $9.2 \pm 0.4^{\mathrm{a}}$ & $8.4 \pm 0.5^{\mathrm{a}}$ & $9.5 \pm 0.9^{\mathrm{a}}$ \\
\hline$\Delta \mathrm{H}_{\mathrm{Total}}(\mathrm{J} / \mathrm{g}$ of fat $)$ & $15.5 \pm 2.3^{\mathrm{a}}$ & $17.6 \pm 1.3^{\mathrm{a}}$ & $12.8 \pm 0.6^{\mathrm{a}}$ & $11.7 \pm 0.7^{\mathrm{a}}$ & $13.3 \pm 1.2^{\mathrm{a}}$ \\
\hline
\end{tabular}

${ }^{a, b}$ Values sharing letters within a row are not significantly different $(P>0.05)$.

${ }^{1}$ Melting behavior was expressed as onset melting temperature $\left(\mathrm{T}_{\mathrm{on}}\right)$, peak melting temperature $\left(\mathrm{T}_{\mathrm{p}}\right)$, and change in enthalpy associated with the melting process $(\Delta \mathrm{H})$, where subscripts 1 and 2 indicate parameters obtained from the first and second melting peaks, respectively. Mean values \pm SEM are reported $(\mathrm{n}=3)$.

important role in phase inversion during butter making, resulting in a harder butter. It is also possible that the total enthalpy of fresh butter is a factor that can influence the firmness of butter. We performed a correlation analysis between hardness and melting parameters. The hardness of butter was highly correlated with enthalpy values of MMF and total enthalpy in fresh butter (Pearson $\mathrm{r}=0.786$ and $0.741 ; P=0.0005$ and 0.002 , respectively). Interestingly, hardness was not correlated with the SFC of fresh butter (Table 3) but was correlated with SFC of the butter after $24 \mathrm{~h}$ of storage at $5^{\circ} \mathrm{C}$ (Pearson $\left.\mathrm{r}=0.608 ; P=0.016\right)$. The $\mathrm{SFC}$ of fresh butter was correlated with SFC of 1-d-old butter (Pearson $\mathrm{r}=0.854 ; P<0.0001$ ).

Overall, we propose that although HIU can increase the volume of dispersed phase, an exposure time of $10 \mathrm{~s}$ is too short to affect droplet size. In cream, milk fat droplets are surrounded by the milk fat globule membrane. When cream is aged, low-melting TAG are crystallized inside the fat droplets and penetrate the membrane of adjunct fat droplets, and this penetration can cause partial coalescence, resulting in development of a continuous network. High-intensity ultrasound might weaken the membrane structure in the cream, allowing for leakage of liquid oil in the fat droplets and resulting in a higher degree of partial coalescence in a shorter time. Indeed, sonication slightly decreased churning time, as shown in Table 4. This early leakage of fat from the fat globule might induce the crystallization of low-melting TAG during churning, as reflected in the data for fresh butter. The formation of these lowmelting-point TAG during churning plays an important role in increasing the SFC of the butter after storage at $5^{\circ} \mathrm{C}$ and increasing the hardness of butter.

Table 2. Melting behavior of fresh and 1-d-old butter (stored for $1 \mathrm{~d}$ at $5^{\circ} \mathrm{C}$ ); the cream was aged at $7.5^{\circ} \mathrm{C}$ for 90 min, sonicated for $0,10,30$, 60 , or $90 \mathrm{~s}$, and churned at $7.5^{\circ} \mathrm{C}$

Sonication time

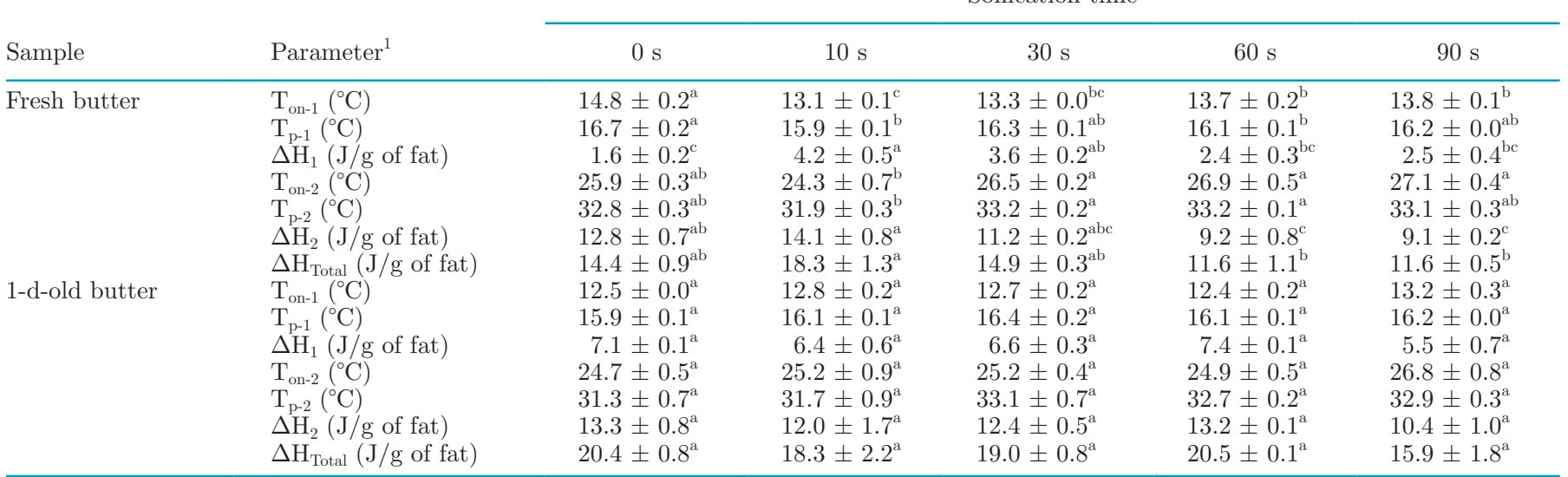

\footnotetext{
${ }^{\mathrm{a}-\mathrm{c}}$ Values sharing letters within a row are not significantly different $(P>0.05)$.

${ }^{1}$ Melting behavior was expressed as onset melting temperature $\left(\mathrm{T}_{\mathrm{on}}\right)$, peak melting temperature $\left(\mathrm{T}_{\mathrm{p}}\right)$, and change in enthalpy associated with the melting process $(\Delta \mathrm{H})$, where subscripts 1 and 2 indicate parameters obtained from the first and second melting peaks, respectively. Mean values \pm SEM are reported $(\mathrm{n}=3)$.
} 


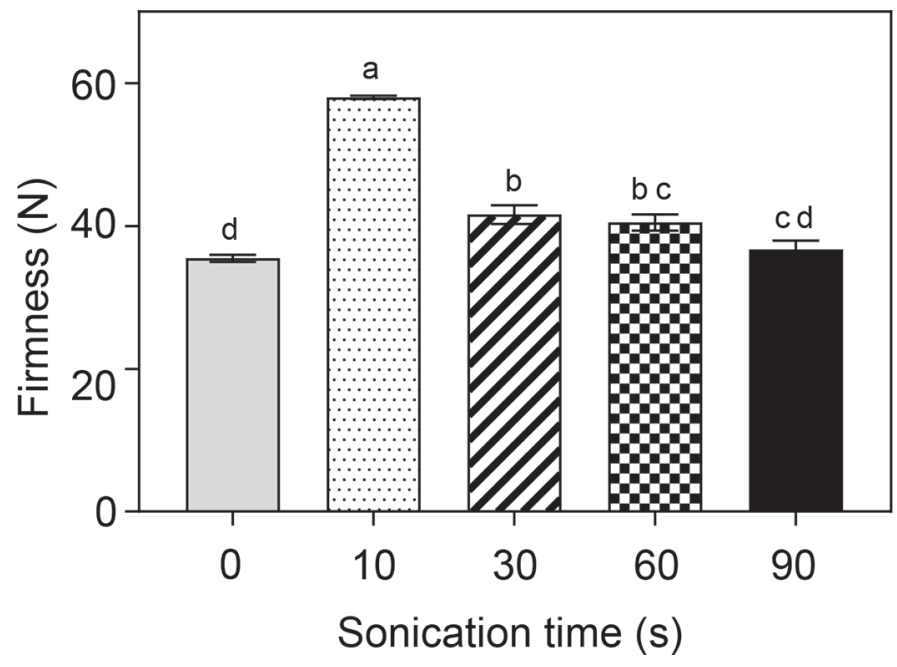

Figure 4. Firmness (N) of butter stored at $5^{\circ} \mathrm{C}$ for $24 \mathrm{~h}$. Butter was made with cream that was aged at $7.5^{\circ} \mathrm{C}$ for $90 \mathrm{~min}$ and sonicated for $0,10,30,60$, or $90 \mathrm{~s}$, and churned at $7.5^{\circ} \mathrm{C}$. The error bars represent SEM $(\mathrm{n}=3)$. Values sharing letters $(\mathrm{a}-\mathrm{d})$ are not significantly different $(P>0.05)$.

\section{CONCLUSIONS}

The current study shows that HIU treatment of cream for $10 \mathrm{~s}$ can be used to increase hardness of butter by promoting crystallization of low-melting-point TAG in fresh butter. When low-melting-point TAG are crystallized during churning, a tighter network can be formed, which results in a harder material. Interestingly, if longer sonication times are used, crystallization of low-melting-point TAG is not promoted and melting of the crystalline network is observed. This study provides information that aids our understanding of factors that affect butter firmness. Furthermore, we have shown that HIU can be used as an additional process technique to modify the texture and melting behavior of butter and to process creams of different fatty acid composition.

Table 3. Solid fat content (SFC) of fresh butter $(0 \mathrm{~h})$ and 1-d-old butter (stored for $24 \mathrm{~h}$ at $5^{\circ} \mathrm{C} ; 24 \mathrm{~h}$ ); the butter was made with cream that was aged at $7.5^{\circ} \mathrm{C}$ for $90 \mathrm{~min}$ and sonicated for $0,10,30,60$, or $90 \mathrm{~s}^{1}$

\begin{tabular}{lcc}
\hline & \multicolumn{2}{c}{ SFC (\%) } \\
\cline { 2 - 3 } Sonication time $(\mathrm{s})$ & $0 \mathrm{~h}$ & $24 \mathrm{~h}$ \\
\hline 0 & $29.5 \pm 0.8^{\mathrm{ab}}$ & $43.7 \pm 0.3^{\mathrm{a}}$ \\
10 & $31.5 \pm 0.1^{\mathrm{a}}$ & $45.2 \pm 0.3^{\mathrm{a}}$ \\
30 & $30.1 \pm 0.1^{\mathrm{a}}$ & $44.1 \pm 0.3^{\mathrm{a}}$ \\
60 & $32.0 \pm 0.5^{\mathrm{a}}$ & $44.5 \pm 0.4^{\mathrm{a}}$ \\
90 & $27.4 \pm 0.3^{\mathrm{b}}$ & $41.5 \pm 0.7^{\mathrm{b}}$ \\
\hline
\end{tabular}

\footnotetext{
${ }^{\mathrm{a}, \mathrm{b}}$ Means within a column with different superscripts differ $(P<0.05)$.
}

${ }^{1}$ Mean values \pm SEM are reported $(\mathrm{n}=3)$.
Table 4. Churning time of cream that was aged at $7.5^{\circ} \mathrm{C}$ for $90 \mathrm{~min}$ and sonicated for $0,10,30,60$, or $90 \mathrm{~s}^{1}$

\begin{tabular}{lc}
\hline Sonication time $(\mathrm{s})$ & Churning time $(\mathrm{s})$ \\
\hline 0 & $1,068.0 \pm 18.0^{\mathrm{a}}$ \\
10 & $952.3 \pm 36.1^{\mathrm{a}}$ \\
30 & $969.3 \pm 46.2^{\mathrm{a}}$ \\
60 & $963.0 \pm 75.3^{\mathrm{a}}$ \\
90 & $919.0 \pm 48.7^{\mathrm{a}}$ \\
${ }^{\mathrm{a}}$ Means within a column with different superscripts differ $(P<0.05)$. \\
${ }^{1}$ Mean values \pm SEM are reported $(\mathrm{n}=3)$.
\end{tabular}

\section{ACKNOWLEDGMENTS}

The authors thank Utah State University (Logan) and the BUILD Dairy Program for funding. This project was approved by the Utah Agricultural Experiment Station as project number 9164 .

\section{REFERENCES}

Abismail, B., J. P. Canselier, A. M. Wilhelm, H. Delmas, and C. Gourdon. 1999. Emulsification by ultrasound: Drop size distribution and stability. Ultrason. Sonochem. 6:75-83.

AOCS. 2009. Solid fat content (SFC) by low resolution nuclear magnetic resonance - The direct method. AOCS, Urbana, IL.

Bobe, G., E. G. Hammond, A. E. Freeman, G. L. Lindberg, and D. C. Beitz. 2003. Texture of butter from cows with different milk fatty acid compositions. J. Dairy Sci. 86:3122-3127.

Chandan, R. C., A. Kilara, and N. P. Shah. 2015. Dairy Processing and Quality Assurance. Wiley-Blackwell, Ames, IA.

Chemat, F., I. Grondin, P. Costes, L. Moutoussamy, A. S. C. Sing, and J. Smadja. 2004. High power ultrasound effects on lipid oxidation of refined sunflower oil. Ultrason. Sonochem. 11:281-285.

Cheng, L. H., C. Y. Soh, S. C. Liew, and F. F. Teh. 2007. Effects of sonication and carbonation on guava juice quality. Food Chem. 104:1396-1401.

Chow, R., R. Blindt, R. Chivers, and M. Povey. 2003. The sonocrystallisation of ice in sucrose solutions: Primary and secondary nucleation. Ultrasonics 41:595-604.

Chow, R., R. Blindt, R. Chivers, and M. Povey. 2005. A study on the primary and secondary nucleation of ice by power ultrasound. Ultrasonics 43:227-230

Cisneros Estevez, A., J. F. Toro-Vazquez, and R. W. Hartel. 2013. Effects of processing and composition on the crystallization and mechanical properties of water-in-oil emulsions. J. Am. Oil Chem. Soc. 90:1195-1201.

Cucheval, A., and R. C. Y. Chow. 2008. A study on the emulsification of oil by power ultrasound. Ultrason. Sonochem. 15:916-920.

Frede, E., and W. Buchheim. 1994. Buttermaking and the churning of blended fat emulsions. Int. J. Dairy Technol. 47:17-27.

Gaikwad, S. G., and A. B. Pandit. 2008. Ultrasound emulsification: effect of ultrasonic and physicochemical properties on dispersed phase volume and droplet size. Ultrason. Sonochem. 15:554-563.

Hickling, R. 1994. Transient, high-pressure solidification associated with cavitation in water. Phys. Rev. Lett. 73:2853-2856.

Higaki, K., S. Ueno, T. Koyano, and K. Sato. 2001. Effects of ultrasonic irradiation on crystallization behavior of tripalmitoylglycerol and cocoa butter. J. Am. Oil Chem. Soc. 78:513-518.

Kaylegian, K. E., and R. C. Lindsay. 1992. Performance of selected milk-fat fractions in cold-spreadable butter. J. Dairy Sci. 75:33073317.

Kiani, H., Z. Zhang, A. Delgado, and D.-W. Sun. 2011. Ultrasound assisted nucleation of some liquid and solid model foods during freezing. Food Res. Int. 44:2915-2921. 
Lopez, C., C. Bourgaux, P. Lesieur, S. Bernadou, G. Keller, and M. Ollivon. 2002. Thermal and structural behavior of milk fat. J. Colloid Interface Sci. 254:64-78.

Luque de Castro, M. D., and F. Priego-Capote. 2007. Ultrasoundassisted crystallization (sonocrystallization). Ultrason. Sonochem. 14:717-724.

MacGibbon, A. K. H., Y. E. Van der Does, B. G. Mabey, G. J. Deller, and N. A. Thomson. 2002. Producing a spreadable butter using modified milkfat. Proc. N. Z. Soc. Anim. Prod. 62:102-107.

Maghsoudlou, Y., M. Alami, M. Mashkour, and M. H. Shahraki. 2016. Optimization of ultrasound-assisted stabilization and formulation of almond milk. J. Food Process. Preserv. 40:828-839.

Martini, S., A. H. Suzuki, and R. W. Hartel. 2008. Effect of high intensity ultrasound on crystallization behavior of anhydrous milk fat. J. Am. Oil Chem. Soc. 85:621-628.

McClements, D. J. 2004. Food Emulsions: Principles, Practices, and Technique. 2nd Edition. Taylor \& Francis, Abingdon, UK.

Nishida, I. 2004. Precipitation of calcium carbonate by ultrasonic irradiation. Ultrason. Sonochem. 11:423-428.

Queiros, M. S., R. Grimaldi, and M. L. Gigante. 2016. Addition of olein from milk fat positively affects the firmness of butter. Food Res. Int. 84:69-75.

Rønholt, S., J. J. Kirkensgaard, T. B. Pedersen, K. Mortensen, and J. C. Knudsen. 2012. Polymorphism, microstructure and rheology of butter. Effects of cream heat treatment. Food Chem. 135:17301739 .
Rønholt, S., J. J. K. Kirkensgaard, K. Mortensen, and J. C. Knudsen. 2014. Effect of cream cooling rate and water content on butter microstructure during four weeks of storage. Food Hydrocoll. $34: 169-176$.

Shanmugam, A., and M. Ashokkumar. 2014. Ultrasonic preparation of stable flax seed oil emulsions in dairy systems - Physicochemical characterization. Food Hydrocoll. 39:151-162.

Suzuki, A. H., J. Lee, S. G. Padilla, and S. Martini. 2010. Altering functional properties of fats using power ultrasound. J. Food Sci 75:E208-E214.

USDA-ERS (Economic Research Service). 2017. Dairy products: Per capita consumption, United States (Annual). USDA-ERS, Washington, DC. Accessed Mar. 16, 2018. https://www.ers.usda.gov/ webdocs/DataFiles/48685/pcconsp_1_.xlsx?v=518.3.

Wiking, L., V. De Graef, M. Rasmussen, and K. Dewettinck. 2009. Relations between crystallisation mechanisms and microstructure of milk fat. Int. Dairy J. 19:424-430.

Yang, B., M. Zhao, J. Shi, N. Yang, and Y. Jiang. 2008. Effect of ultrasonic treatment on the recovery and DPPH radical scavenging activity of polysaccharides from longan fruit pericarp. Food Chem. 106:685-690.

Ye, Y., A. Wagh, and S. Martini. 2011. Using high intensity ultrasound as a tool to change the functional properties of interesterified soybean oil. J. Agric. Food Chem. 59:10712-10722. 